\title{
Pharmacokinetics of florfenicol by gavage feeding or medicated feed in rainbow trout (Oncorhynchus mykiss)
}

\begin{abstract}
The most cultivated freshwater species is rainbow trout in aquaculture worldwide. This study was aimed at pharmacokinetics of florfenicol administrated to rainbow trout (Oncorhyncus mykiss) by oral gavages (through a tube leading down the throat to the stomach) and medicated feed. 132 healthy rainbow trout weighing $140 \pm 10 \mathrm{~g}$ were randomly selected and after 2 weeks acclimation period, florfenicol were administrated as oral gavages and medicated feed at single dose $10 \mathrm{mg} / \mathrm{kg}^{-1}$ body weight (B.W) to individual fish Plasma samples were collected at 0, 0.5, 1, 3, 6, 9, 12, 24, 36, 48 and $72 \mathrm{~h}$ after feeding and analyzed by high performance liquid chromatography (HPLC) method. The data obtained from plasma concentrations of florfenicol after oral gavages and feed medicated routes were analyzed by SPSS version 16 , Mann-Whitney U, ANOVA tests and $(P<0.05)$ was considered significant. The maximum concentration $\left(\mathrm{C}_{\max }\right)$ was gained at $12 \mathrm{~h}$ for gavages route $\left(4.68 \mu \mathrm{g} / \mathrm{ml}^{-1}\right)$, but at $9 \mathrm{~h}$ for medicated feed $\left(6.1 \mu \mathrm{g} / \mathrm{ml}^{-1}\right)$. The maximum level concentration of florfenicol in medicated feed route was higher than oral gavages route $(P<0.05)$. It seems that feed can increase absorbance of florfenicol. Also, interestingly the $\mathrm{C}_{\max }$ in medicated feed route rapidly reached and the decreasing process of drug showed less elimination in versus of time.
\end{abstract}

Keywords: rainbow trout, florfenicol, pharmacokinetics, gavages route, medicated feed route
Volume 7 Issue I - 2018

\author{
Behnam Pourmolaie,' Hamid Reza E shraghi,' \\ Masoud Haghighi, ${ }^{2}$ Seyed Alireza Mortazavi, ${ }^{3}$ \\ Mostafa Sharif Rohani ${ }^{4}$ \\ 'Department of Veterinary Basic Sciences, Science and Research \\ Branch, Islamic Azad University, Iran \\ ${ }^{2}$ Coldwater Fishes Research Center (CFRC), Iranian Fisheries \\ Science Research Institute,Agricultural Research Education and \\ Extension Organization (AREEO), Iran \\ ${ }^{3}$ Department of Pharmaceutics, School of Pharmacy, Shahid \\ Beheshti University of Medical Science, Iran \\ ${ }^{4}$ Iranian Fisheries Science Research Institute, Agricultural \\ Research Education and Extension Organization (AREEO), Iran
}

Correspondence: Masoud Haghighi, Coldwater Fishes Research Center (CFRC), Tonekabon, Iran, Tel +989I22I55I05, Fax+98I I54345534, Email masoud 126@yahoo.com

\section{Introduction}

The most cultivated freshwater species is rainbow trout in aquaculture worldwide. Fish production is annually increasing in Europe, Asia and American continents. ${ }^{1}$ Germany, France, Italy, Iran and United States are countries which large production of fish has been registered. ${ }^{2}$ In aquaculture, bacterial diseases are common with high density, so for prophylaxis or treatment of disease, the use of antibacterial agents is inevitable. ${ }^{3}$

In the past, one of the main antibacterial agents in aquaculture was chloramphenicol which due to bone-marrow depression and irreversible aplastic anaemia in human, its use was limited until florfenicol, fluorinated analogue of thiamphenicol (Figure 1), synthesized and approved for veterinary use. ${ }^{4}$ Approvement of florfenicol had been done for use in fresh water-reared salmonids at 2007 by the U.S. Food and Drug Administration Centre for Veterinary Medicine. Florfenicol has great potential for treatment of bacterial infections of fish. ${ }^{5}$ It is more active than thiamphenicol, chloramphenicol, and dangerous bacteria such as Aeromonas salmonicida, Vibrio Salmonicida, and Edwardsiella ictaluri are susceptible to florfenicol. Oral administration of florfenicol for treatment of bacterial infections of captive fish has been done under the trade names of Aquaflor ${ }^{\circledR}$ and Aquafen $^{\circledR}$ in Canada and Europe, respectively. ${ }^{6}$

Oral administration of florfenicol could be either as oral solution or medicated feed. Several studies have been done about pharmacokinetics of florfenicol in trout as oral and intramuscular administrations $s^{7,8}$ but this study was aimed at pharmacokinetics of florfenicol following gavage and medicated feed administrations in rainbow trout.<smiles>CS(=O)(=O)c1ccc([C@@H](O)[C@H](CF)NC(=O)C(Cl)Cl)cc1</smiles>

Figure I Chemical structure of florfenicol (fluorinated analogue of thiamphenicol).

\section{Materials and Methods}

\section{Chemicals}

Florfenicol standard was purchased from Sigma chemicals Co., USA and chloramphenicol standard was purchased from Merck Co, Germany. Stock standard solutions of florfenicol and chloramphenicol were prepared as $1 \mathrm{mg} / \mathrm{ml}^{-1}$ and $0.5 \mathrm{mg} / \mathrm{ml}^{-1}$ by dissolving each drug in methanol, respectively and stored at $-20^{\circ} \mathrm{C}$.

\section{Fish}

132 healthy rainbow trout (Oncorhynchus mykiss) weighing $140 \pm 10 \mathrm{~g}$ obtained from a trout breeding centre (2000 center, Tonekabon, Iran) were reared in fresh water. The fish were brought to cement tanks of Coldwater Fishes Research Centre which was disinfected 1 day prior to transmission. Water constant flow of $720 \mathrm{~L} / \mathrm{h}$ ${ }^{1}$ with oxygen content of $(92 \pm 2) \%$, PH $(7.2 \pm 0.1)$ and temperature of $14-15^{\circ} \mathrm{C}$ in cement tanks were established. The fish were fed with 
pellet (\%36-38 protein) in amount of $2 \%$ of the body weight TID for 2 weeks. After acclimation period ( 2 weeks), the fish were staved for 1 day before administration of drug.

\section{Drug and drug administration}

Florfenicol powder was donated by Behvazan Company (Tehran, Iran). Oral suspension of florfenicol $\left(2.5 \mathrm{mg} / \mathrm{ml}^{-1}\right)$ was prepared by dissolving florfenicol powder in propylene glycol. Medicated feed was prepared by blending the drug in feed $\left(10 \mathrm{mg} / \mathrm{g}^{-1} \mathrm{feed}\right){ }^{7,8} \mathrm{~A}$ single dose of $10 \mathrm{mgkg}^{-1}$ body weight (B.W) florfenicol was given to individual fish.

\section{Sampling}

The samples were taken at $0,0.5,1,3,6,9,12,24,36,48$ and $72 \mathrm{~h}$ after drug administration (oral gavages and medicated feed route). Blood samples were taken from caudal vein using a heparinized $2.5 \mathrm{ml}$ syringe and plasma was isolated by centrifugation at $3000 \mathrm{rpm}$ for $10 \mathrm{~min}$. all samples were instantly frozen and stored at $20^{\circ} \mathrm{C}$ until analysis.

\section{Sample preparation}

$0.5 \mathrm{ml}$ plasma sample was added to $30 \mu 1$ chloramphenicol $(2 \mu \mathrm{g}$ $\mathrm{ml}^{-1}$ ) for use as the internal standard. Each sample was whirl mixed for $2 \mathrm{~min}$ and then $3.5 \mathrm{ml}$ ethyl acetate was added and centrifuged at 3500 $\mathrm{rpm}$ for $1 \mathrm{~min}$ to precipitate proteins. $2.5 \mathrm{ml}$ supernatant was removed and evaporated to dryness under a gentle steam of nitrogen at $40^{\circ} \mathrm{C}$. The residue was dissolved in $0.5 \mathrm{ml}$ of mobile phase solution (water - acetonitrile, 75:25, v/v) and after centrifugation, filtered through a syringe filter $(0.45 \mu \mathrm{m})$, and $100 \mu 1$ were injected on the HPLC column.

\section{Chromatographic condition}

The analyses were performed by HPLC system (waters 2695, U.K), consisted of a reaction pump, Intelligent pump and waters 486 detector at $234 \mathrm{~nm}$. The separation was performed at $40^{\circ} \mathrm{C}$ on a $200 \mathrm{~mm} \times 4.6 \mathrm{~mm}$ I.D. ODS-A column packed with $5 \mu \mathrm{m}, 120$-A C18 stationary phase. The mobile phase was water- acetonitrile $(75,25 \mathrm{~V} / \mathrm{V})$ which filtered through a $0.45 \mu \mathrm{m}$ filter and degassed by sonication $(5 \mathrm{~min})$. The flow rate was $2.5 \mathrm{ml} / \mathrm{min}^{-1}$.

\section{Analyze quantification}

Working standard solutions $(0.1,0.25,0.5,1,2.5,5,10,20$ and 25$)$ encompassing the expected concentrations of florfenicol were injected on the HPLC system to generate a calibration curve with coefficient of determination $\left(r^{2}\right)$ exceeding 0.997 . The recovery rate for florfenicol was $92.3-98.1 \%$. The limit of quantification was $0.03 \mu \mathrm{g} / \mathrm{gr}^{-1}$.

\section{Statistical analysis}

The data obtained from plasma concentrations of florfenicol after gavage and medicated feed routes were analyzed by SPSS version 16, Mann-Whitney $\mathrm{U}$, ANOVA tests and $(\mathrm{P}<0.05)$ was considered significant.

\section{Results and Discussion}

In the present study results show that the mean concentrations of florfenicol in plasma versus time were shown in table 1. Plasma concentration of florfenicol after $0.5 \mathrm{~h}$ reached $1.66 \mu \mathrm{g} / \mathrm{ml}^{-1}$ and maximum plasma concentration $\left(4.68 \mu \mathrm{g} / \mathrm{ml}^{-1}\right)$ was gained at 12 $\mathrm{h}$ for oral gavages route but plasma concentration for medicated feed route after $0.5 \mathrm{~h}$ reached $1.60 \mu \mathrm{g} / \mathrm{ml}^{-1}$ and maximum plasma concentration was $6.1 \mu \mathrm{g} / \mathrm{ml}^{-1}$ at $9 \mathrm{~h}$. The drug level steadily decreased and reached $0.49 \mu \mathrm{g} / \mathrm{ml}^{-1}, 0.79 \mu \mathrm{g} / \mathrm{ml}^{-1}$ for oral gavages and medicated feed administrations after $72 \mathrm{~h}$, respectively. Pharmacokinetics parameters for florfenicol are shown in table 2. Plasma concentrations of florfenicol in medicated feed route were significantly higher than plasma concentration of florfenicol in gavages route $(\mathrm{P}<0.05)$.

Table I Concentrations of florfenicol in plasma after oral gavages and medicated feed routes

\begin{tabular}{lllllllllll}
\hline Oral administration & \multicolumn{10}{c}{ Time(h) } \\
\hline & 0.5 & 1 & 3 & 6 & 9 & 12 & 24 & 36 & 48 & 72 \\
Gavage route $\left(\mu \mathrm{g} / \mathrm{ml}^{-1}\right)$ & 1.66 & 2.21 & 2.96 & 2.1 & 3.1 & 4.68 & 1.34 & 1.91 & 0.78 & 0.49 \\
Medicated feed route $\left(\mu \mathrm{g} / \mathrm{ml}^{-1}\right)$ & 1.6 & 3.1 & 4.2 & 5.6 & 6.1 & 4.9 & 3.1 & 1.58 & 0.93 & 0.79 \\
\hline
\end{tabular}

Table 2 Pharmacokinetics parameters for florfenicol after oral gavages and medicated feed routes

\begin{tabular}{llll}
\hline & Dose & $\mathbf{C}_{\max }$ & $\mathbf{T}_{\max }$ \\
\hline Oral Administration & $\mathrm{mgkg}^{-1}$ & $\mu \mathrm{gml}^{-1}$ & $\mathrm{~h}$ \\
Gavage route & 10 & 4.68 & 12 \\
Feed medicated route & 10 & 6.1 & 9 \\
\hline
\end{tabular}

Several studies have performed on pharmacokinetic of florfenicol in different fish species. Oral administration is common route of drug administration in fish. ${ }^{8,9}$ This study was done to evaluate the pharmacokinetic of florfenicol following gavage and medicated feed administration in rainbow trout. Maximum level concentration in gavage rout reached after $12 \mathrm{~h}\left(4.68 \mu \mathrm{g} / \mathrm{ml}^{-1}\right)$ but maximum level concentration in feed medicated rout reached after $9 \mathrm{~h}\left(6.1 \mu \mathrm{g} / \mathrm{ml}^{-1}\right)$ with dose of $10 \mathrm{mg} / \mathrm{kg}^{-1}$. Feng et al. (6) have reported maximum level concentration in oral rout in tilapia $4.46 \mu \mathrm{g} / \mathrm{ml}^{-1}$ at $22^{\circ} \mathrm{C}$ which is in agreement with our study in oral gavages route.

The maximum level concentration of florfenicol in medicated feed route was higher than gavage route. It seems that feed can increase absorbance of florfenicol.

Also, interestingly the maximum level concentration in medicated feed route rapidly reached. Meinertz et al. ${ }^{10}$ have reported florfenicol 
concentration in skin-on fillets in the recirculating aquaculture system (RAS) $11.58 \mu \mathrm{g} / \mathrm{ml}^{-1}$ at $13^{\circ} \mathrm{C} . \mathrm{T}_{\max }$ of $12 \mathrm{~h}$ in plasma in oral gavages route was in agreement with the results of Feng et al. ${ }^{6}$ in tilapia and Martinsen et al. ${ }^{11}$ in Atlantic salmon after oral dosing at $10 \mathrm{mg} / \mathrm{kg}^{-1}$ florfenicol. In this study, the decreasing process of drug in medicated feed route showed less elimination in versus of time. Martinsen et al. ${ }^{11}$ have reported rapid absorption and less elimination in medicated feed Feed medicated route is a safe method with high efficiency which is confirmed by Straus et al. ${ }^{12}$ and is in agreement with our study. Cao et al. ${ }^{13}$ have reported $\mathrm{C}_{\max } 10.8 \mu \mathrm{g} / \mathrm{ml}^{-1}$ after $8 \mathrm{~h}$ in top mouth culter (Culter alburnus) which was higher than our results. In conclusion, the present study showed that florfenicol as medicated feed route was better than gavage route both higher and rapid concentration in rainbow trout.

\section{Acknowledgment}

The authors wish to thanks the Dr. Ali kazemi, Dr. Fariborz Shojaee, Ali Abadi and Dr. karami for technical assistance.

\section{Conflict of Interest}

None.

\section{References}

1. Biancotto G, Contiero L, Benetti C, et al. Depletion of chloramphenicol in trout after a hypothetic therapeutic treatment. Analytica Chimica Acta. 2009;637(1-2):173-177.

2. Food and Agriculture Organization in the United States fisheries and aquaculture department. 2011. Cultured Aquatic Species Information program Oncorhynchus mykiss. Walbaum. 1792.

3. Lu XW, Dang Z, Yang C. Preliminary investigation of chloramphenicol in fish, water and sediment from freshwater aquaculture pond. Int J Environ Sci Technol. 2009;6(4):597-604.
4. Carty D, Bowker JD, Bowman MP, et al. Calculate amount of aquaflor (florfenicol, 50\%) to add to fish feed. Drug Research Information Bulletin of the U.S Fish and Wildlife Service. Aquatic Animal Drug Approval Partnership. 2007.

5. USFDA CVM (U.S Food and Drug Administration, center for veterinary medicine). Guidance for industry. General principles for evaluating the safety of compounds used in food-producing animals. U.S Department of Health and Human Services. 2006.

6. Feng JB, Jia XP, Li LD. Tissue distribution and elimination of florfenicol in tilapia (Oreochromis niloticus $\times$ O. caureus) after a single oral administration in freshwater and seawater at $28^{\circ} \mathrm{C}$. Aquaculture. 2008;276(1-4):29-35.

7. Park Bk, Lim JH, Kim MS, et al. Pharmacokinetics of florfenicol and its metabolite, florfenicol amine, in the Korean catfish (Silurus asotus). J Vet Pharmacol Ther. 2006;29(1):37-40.

8. Horsberg TE, Martinsen B, Varma KJ. The disposition of 14C-florfenicol in Atlantic salmon (Salmo salar). Aquaculture. 1994;122(2-3):97-106.

9. Yanong RPE, Curtis EW, Simmons R, et al. Pharmacokinetic studies of florfenicol in koi carp and three spot gourami (Trichogaster trichopterus) after oral and intramuscular treatment. J Aquatic Animal Health. 2005; 17(2): 129-137.

10. Meinertz JR, Schreier TM, Bernardy JA. Evaluation of a method for determining concentrations of isoeugenol, an AQUI-S residue, in fillet tissue from freshwater fish species. J AOAC Int. 2008;91(4):884-891.

11. Martinsen B, Horsberg TE, Varma KJ, et al. Single dose pharmacokinetic study of florfenicol in Atlantic salmon (Salmo salar) in seawater at $11^{\circ} \mathrm{C}$. Aquaculture. 1993;112(1):1-11.

12. Straus LD, Bowker JD, Bowman MP, et al. Safety of aquaflor-Medicated Feed to Sunshine Bass. North American Journal of Aquaculture. 2012;74(1): 1-7.

13. Cao XJ, Wang WM, Song F. Anatomical and Histological Characteristics of the intestine of the Top mouth culter (Culter alburnus). Anatomia Histologia Embryologia. 2011;40(4):292-298. 